Article

\title{
Evaluation of Factors Affecting Direct Organogenesis in a Somatic Tissue Culture of Sinningia speciosa (Lodd.) Hiern
}

\author{
Aušra Blinstrubiené *(D), Natalija Burbulis ${ }^{\mathbb{D}}$, Vaida Jonytiené ${ }^{\mathbb{D}}$ and Ramunè Masiené \\ Institute of Biology and Plant Biotechnology, Agriculture Academy, Vytautas Magnus University, \\ Donelaicio str. 58, 44248 Kaunas, Lithuania; natalija.burbulis@vdu.lt (N.B.); vaida.jonytiene@vdu.lt (V.J.); \\ ramune.masiene@vdu.lt (R.M.) \\ * Correspondence: ausra.blinstrubiene@vdu.lt; Tel.: +370-637-752-265
}

Received: 28 September 2020; Accepted: 11 November 2020; Published: 13 November 2020

\begin{abstract}
In this study, the influence of genotype, concentration of thidiazuron (TDZ), and explant position on the culture medium in organogenesis in a somatic tissue culture of two gloxinia cultivars was investigated. Isolated explants cultured on the medium containing TDZ formed adventitious shoots directly without an intervening callus phase. Explant regeneration frequency varied depending on the genotype, TDZ concentration, and explant position on the medium. The analysis of variance revealed that cultivar $(\mathrm{C})$, TDZ concentration $(\mathrm{T})$, position of explant on culture medium $(\mathrm{P})$, and the interaction of $\mathrm{C} \times \mathrm{T}, \mathrm{C} \times \mathrm{P}, \mathrm{T} \times \mathrm{P}$, and $\mathrm{C} \times \mathrm{T} \times \mathrm{P}$ significantly influenced the frequency of shoot formation. However, the effect of interface $\mathrm{C} \times \mathrm{P}$ and $\mathrm{C} \times \mathrm{T} \times \mathrm{P}$ on the number of shoots per explant was not significant. "Snowy" leaf explants manifested a significantly higher mean shoot formation frequency $(p<0.01)$ in comparison with the cultivar "Midnight Purple". The medium enriched with $3.5 \mu \mathrm{M}$ TDZ resulted in the highest organogenesis frequency, while the highest shoot number per explant was acquired on medium supplemented with $4.0 \mu \mathrm{M}$ TDZ. The explants of the tested cultivars cultured on the medium with the adaxial side down showed a significantly higher $(p<0.01)$ shoot formation frequency in comparison with explants cultured on the medium with the abaxial side, and they showed a higher mean number of shoots per explant. An effective method for in vitro organogenesis of Sinningia speciosa (Lodd.) Hiern without an intervening callus phase was established.
\end{abstract}

Keywords: cytokinin; explant position; genotype; gloxinia; shoot

\section{Introduction}

Gloxinia (Sinningia speciosa (Lodd.) Hiern) is very valuable ornamental plant that is widely cultivated worldwide for commercial purposes. It is a plant with large oval leaves and varicolored single or double flowers [1,2]. The mentioned species belongs to the family Gesneriaceae, whose origin is Brazil and currently is widely cultivated as a garden and house plant. For commercial purposes, gloxinias are generally propagated by seed or by vegetative propagation from leaves and stems of mature plants after flowering. However, propagation by seeds is not efficient enough because of a low germination rate and the fact that seed-propagated plants might demonstrate unwanted features and lack homogeneity [3]. Furthermore, vegetative propagation requires considerable space and is slow, taking about $6-7$ months $[4,5]$. Micropropagation by tissue culture enables the production of a large quantity of identical plants year-round without compromising quality. For this reason, plant propagation by biotechnological approaches has been increasing worldwide, and in 2006, more than 156 genera of ornamental plants were propagated by in vitro techniques in plant tissue culture laboratories in many countries [6]. Moreover, the employment of an effective in vitro plant 
regeneration system might expand genetic diversity through the regeneration and screening of valuable somaclonal variations [3].

In vitro micropropagation has been reported for some species of the Gesneriaceae family, such as Saintpaulia ionantha [7], Aeschynanthus radicans [8], Titanotrichum oldhamii [3], and Primulina tamiana [9]. Organogenesis in Sinningia speciosa has been induced from sepal segments of floral buds [10], petal segments [11], shoot apices [12], and leaf explants [2,13-15]. A few research groups have reported indirect shoot regeneration of gloxinia from somatic tissues through callus formation. In some cases, a medium supplemented with cytokonin 6-benzylaminopurine (BAP) and auxin $\alpha$-naphthalene acetic acid (NAA) has been suggested for callus induction and subsequent adventitious bud formation [1,16]. Xu et al. [13] reported two methods for the regeneration of gloxinia from leaf explants: direct organogenesis in medium containing $2.0 \mathrm{mg} \mathrm{L}^{-1} \mathrm{BAP}$ and $0.2 \mathrm{mg} \mathrm{L}^{-1} \mathrm{NAA}$, and indirect organogenesis in medium enriched by $1.0-5.0 \mathrm{mg} \mathrm{L}^{-1} \mathrm{NAA}$.

Thidiazuron (TDZ) is a urea derivative, lacking a purine ring, which has been found to be more effective in comparison with purine type cytokinins [17]. According to a research report, TDZ has both cytokinin and auxin-cytokinin properties [18]. A significant effect of thidiazuron on organogenesis has been reported for many plants, such as Stevia rebaudiana Bertoni [19], Rubus fruticosus L. [20], and Fragaria $x$ ananasa [21]. Guo et al. [22] found that thidiazuron exhibits strong cytokinin activity and induces efficient morphogenesis in in vitro cultures.

Indirect organogenesis through callus formation may result in somaclonal variations which are undesirable for micropropagation of identical plants; therefore, direct organogenesis without a callus phase is very important for commercial micropropagation of gloxinia. In spite of the high ornamental value of Sinningia speciosa, few attempts have been made to multiply this plant through in vitro cultures without an intervening callus phase. Pang and co-authors reported that a combination of $1.0 \mathrm{mg} \mathrm{L}^{-1}$ gibberellin (GA) with $0.4 \mathrm{mg} \mathrm{L}^{-1}$ 6-benzyladenine (BA) promoted the increase in flower buds formation from sepal segments [10], while a combination of $1.0 \mathrm{mg} \mathrm{L}^{-1} \mathrm{GA}$ with $0.5 \mathrm{mg} \mathrm{L}^{-1}$ BA was more suitable for flower bud regeneration from petal segments [11]. The highest efficiency of shoot organogenesis from leaf explants was determined on Murashige and Skoog (MS) medium with $2.0 \mathrm{mg} \mathrm{L}^{-1}$ BAP and $0.1 \mathrm{mg} \mathrm{L}^{-1}$ NAA in Park with co-authors' [14] studies. Moreover, this research group found that addition of silver nitrate and putrescine into an induction medium increased the shoot number and length. Sharma and Sharma [15] found that the highest shoot induction frequency from leaf discs was obtained on MS medium supplemented with $2.0 \mathrm{mg} \mathrm{L}^{-1} \mathrm{BAP}$ and $0.5 \mathrm{mg} \mathrm{L}^{-1} \mathrm{NAA}$. To the best of our knowledge, the effect of the position of explants on culture medium in gloxinia micropropagation has not been previously reported. Therefore, the aim of this research was to evaluate the effect of TDZ concentration and explant position on the culture medium on direct organogenesis from leaf explants of two gloxinia cultivars.

\section{Materials and Methods}

\subsection{Plant Material}

This investigation was performed with the gloxinia cultivars "Snowy" and "Midnight Purple". Donor plants were maintained in a growth chamber with a $16: 8$-h photoperiod, $25 / 22{ }^{\circ} \mathrm{C}$ (day/night) temperature, and $100 \mu \mathrm{mol} \mathrm{m} \mathrm{m}^{-2} \mathrm{~s}^{-1}$ light density.

\subsection{Induction of In Vitro Organogenesis from Leaf Explants}

Healthy mature young leaves were used as explants, and they were washed thoroughly under running tap water. The surfaces of leaf discs $(20 \times 20 \mathrm{~mm})$ were disinfected in $70 \%$ ethanol for $1 \mathrm{~min}$ and then in $1.2 \%$ active chlorine solution for $3 \mathrm{~min}$. They were then three times washed with sterile distilled water. For adventitious shoot induction, the explants were placed with the adaxial (Figure 1a) or abaxial (Figure 1b) side on basal Murashige and Skoog (MS) [23] medium either excluding plant growth regulators (PGRs) or with $0.5,1.0,1.5,2.0,2.5,3.0,3.5$, or $4.0 \mu \mathrm{M}$ of thidiazuron (TDZ). Media 
were supplemented with $30.0 \mathrm{~g} \mathrm{~L}^{-1}$ sucrose and solidified with $8.0 \mathrm{~g} \mathrm{~L}^{-1}$ agar, and the $\mathrm{pH}$ was adjusted to 5.5. Culture media $(20 \mathrm{~mL})$ were dispensed into Petri dishes $90 \mathrm{~mm}$ in diameter and then sealed with parafilm. Explants were cultivated in a growth chamber at $22 / 18^{\circ} \mathrm{C}$ (day/night) under a $16: 8-\mathrm{h}$ photoperiod at a light intensity of $50 \mu \mathrm{mol} \mathrm{m} \mathrm{m}^{-2} \mathrm{~s}^{-1}$. After 28 days of culture, the explant regeneration frequency and adventitious shoot (approximately $5-8 \mathrm{~mm}$ ) numbers were recorded.

(a)
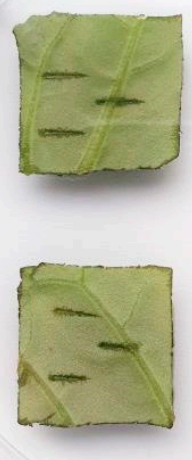
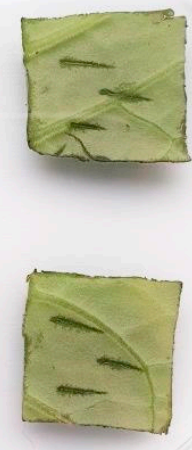

(b)
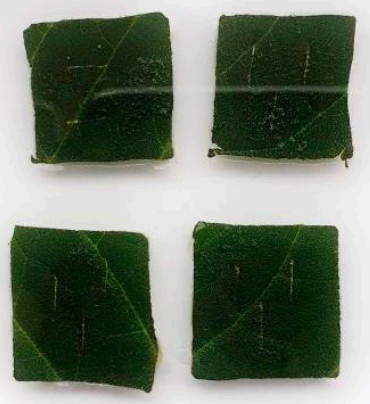

Figure 1. The explants placed on medium with the adaxial (a) and abaxial (b) side down $($ scale bar $=1.0 \mathrm{~cm})$.

\subsection{Root Formation and Plantlet Acclimatization}

After three replications from each treatment, 24 to 2604 shoots were obtained depending on the cultivar (C), TDZ concentration (T) and position of the explant on the culture medium (P) interaction. Twenty regenerated shoots from each treatment were removed from the explants, displaced for rooting to the MS medium containing macro- and microsalts with concentrations reduced by $50 \%$, and supplemented with $0.1 \mu \mathrm{M} \alpha$-naphthylacetic acid (NAA) and $10.0 \mathrm{~g} \mathrm{~L}^{-1}$ sucrose. The medium was solidified with $8.0 \mathrm{~g} \mathrm{~L}^{-1}$ agar, and the $\mathrm{pH}$ was adjusted to 5.7. Regenerated shoots were cultivated at $25 / 22{ }^{\circ} \mathrm{C}$ (day/night) under a 16:8-h photoperiod at a light intensity of $50 \mu \mathrm{mol} \mathrm{m}{ }^{-2} \mathrm{~s}^{-1}$. Plantlets with roots were removed from medium, washed with water to remove the medium from the roots, and planted to plastic pots with sterilized soil and vermiculite in a 1:1 ratio. The plants were initially covered with a plastic bag and maintained in a growth chamber at $25 / 22^{\circ} \mathrm{C}$ (day/night) under a $16: 8-\mathrm{h}$ photoperiod, at a light intensity of $100 \mu \mathrm{mol} \mathrm{m}^{-2} \mathrm{~s}^{-1}$ for 10 days, and then they were transferred to the glasshouse.

\subsection{Statistical Analysis}

Experiments were arranged in an absolutely randomized design with three replicates per treatment $(\mathrm{C} \times \mathrm{T} \times \mathrm{P})$ and 48 explants per replicate. Percentage of shoot formation frequency ((number of explants with adventitious shoots/total number of explants) $\times 100 \%$ ) and the number of adventitious shoots (number of adventitious shoots/number of explants forming adventitious shoots) were computed by STAT 1.55 from "SELEKCIJA" and "IRRISTAT" [24]. The mean value of explant regeneration frequency and SE for every genotype were computed based on the number of independent replications. All percentage values were transformed using the arcsine square root $(\sqrt{ } \mathrm{P})[25]$ to normalize the distribution before variance analysis was performed. The effects of the factors (cultivar, TDZ concentration, position of explant on culture medium) and their interaction on 
direct regeneration were investigated by three-way analysis of variance. Tukey tests were conducted for multiple comparisons.

\section{Results and Discussion}

\subsection{Adventitious Shoot Formation from Leaf Explants}

The leaf discs of the investigated cultivars that were grown on medium without growth regulators demonstrated no response, even after 4 weeks of culture, and consequently grew to be necrotic. On the medium supplemented with TDZ, the isolated explants formed adventitious shoots directly without a callus phase. Explant regeneration frequency varied from 6.9 to $96.3 \%$ depending on the genotype, TDZ, and explant position on the medium (Figure 2). 

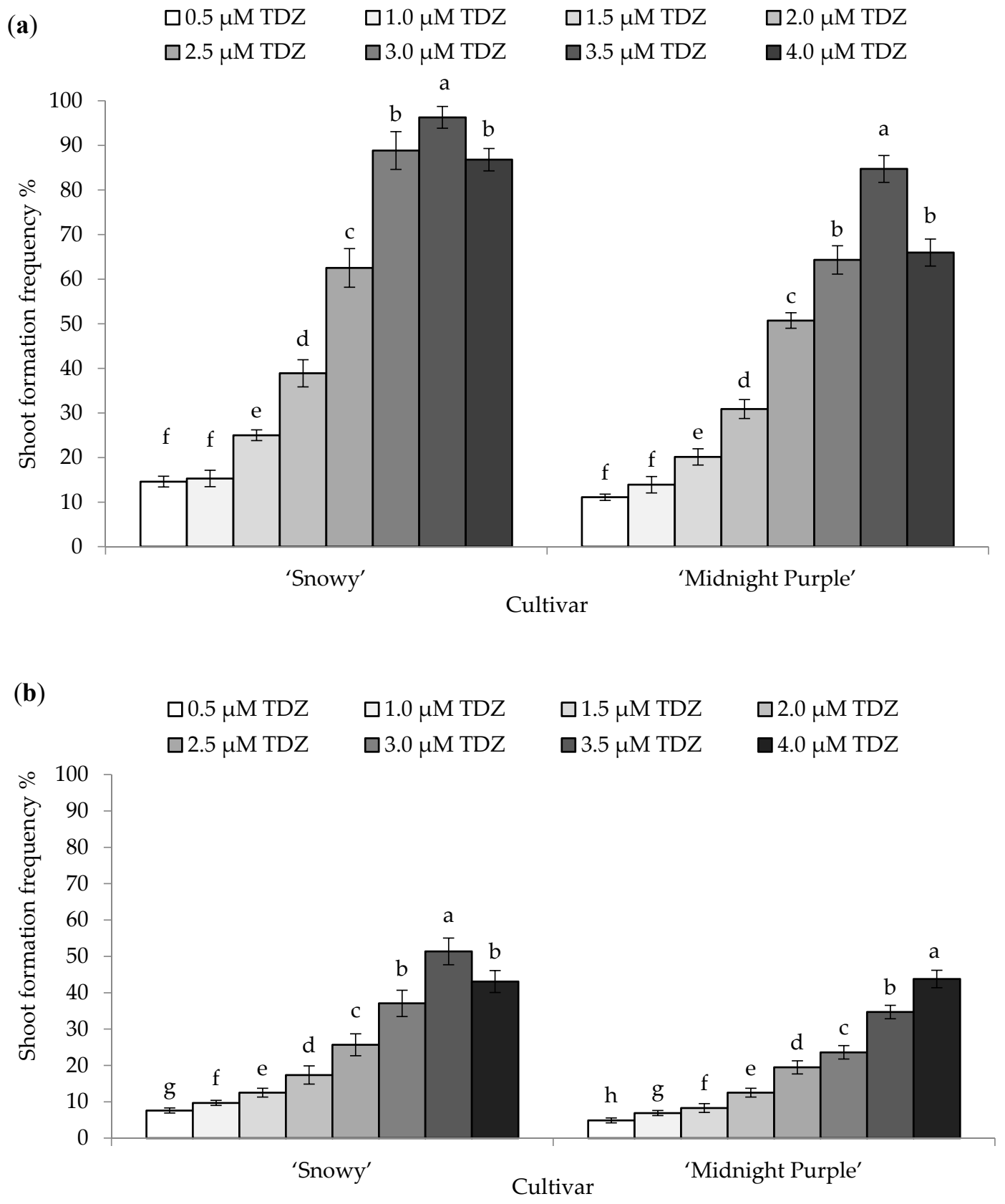

Figure 2. Effect of thidiazuron (TDZ) concentration on gloxinia shoot formation frequency. Means \pm SE of cultivars followed by the same letter were not significantly different at $p<0.01$. ((a)—adaxial side down, (b)—abaxial side down).

Addition to the medium of TDZ at $3.5 \mu \mathrm{M}$ promoted the highest shoot formation frequency in both studied cultivars placed with the adaxial side on the medium and in the "Snowy" cultivar cultured with the abaxial side on the medium, while TDZ at $4.0 \mu \mathrm{M}$ promoted the highest shoot formation frequency in the "Midnight Purple" cultivar placed on the abaxial side of the medium.

The highest number of shoots per explant for both cultivars was observed on the medium supplemented with $4.0 \mu \mathrm{M}$ TDZ, independent of explant position on the culture medium (Figure 3). 

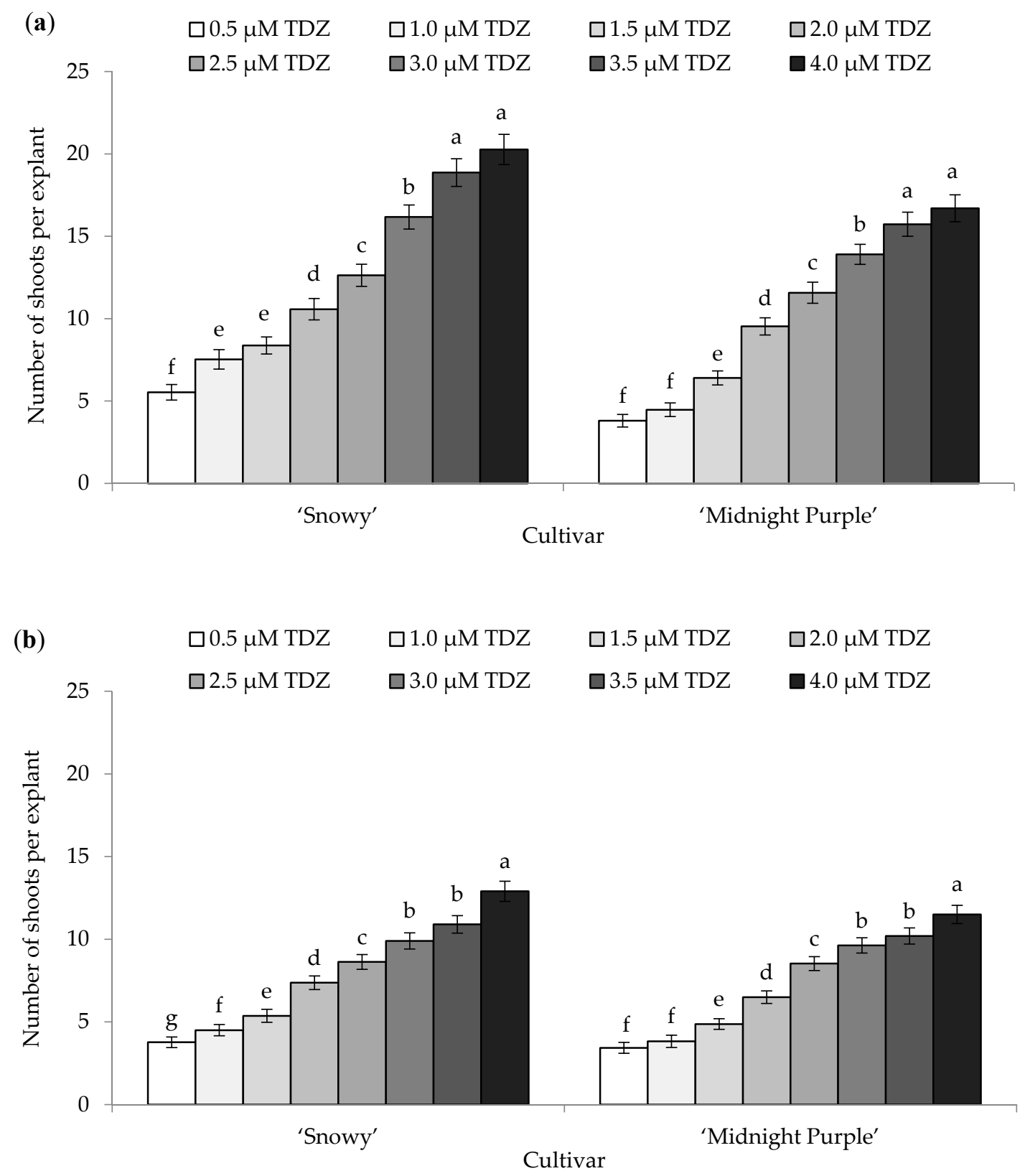

Figure 3. Effect of TDZ concentration on gloxinia number of shoots per explant. Means \pm SE of cultivars followed by the same letter were not significantly different at $p<0.01$. ((a)—adaxial side down, (b)—abaxial side down).

The highest number of adventitious shoots was observed from "Snowy" leaf discs placed with the adaxial side on the medium supplemented with TDZ at $4.0 \mu \mathrm{M}$ (Figure 3a).

The analysis of variance showed significant effect of cultivar (C), TDZ concentration (T), position of the explant on the culture medium $(\mathrm{P})$, and the interactions $\mathrm{C} \times \mathrm{T}, \mathrm{C} \times \mathrm{P}, \mathrm{T} \times \mathrm{P}$, and $\mathrm{C} \times \mathrm{T} \times \mathrm{P}$ on the frequency of shoot formation. However, the effect of the interactions $\mathrm{C} \times \mathrm{P}$ and $\mathrm{C} \times \mathrm{T} \times \mathrm{P}$ on the number of shoots per explant was not significant (Table 1). 
Table 1. The variance analysis of investigated factors on shoot formation frequency and number of shoots per explant.

\begin{tabular}{lcccc}
\hline \multicolumn{1}{c}{ Effect } & $\begin{array}{c}\text { F-Values of Shoot } \\
\text { Formation Frequency (\%) }\end{array}$ & $\begin{array}{c}p \text {-Values for Shoot } \\
\text { Formation Frequency }\end{array}$ & $\begin{array}{c}\text { F-Values of Number of } \\
\text { Shoots per Explant }\end{array}$ & $\begin{array}{c}p \text {-Values for Number } \\
\text { of Shoots per Explant }\end{array}$ \\
\hline Cultivar (C) & $95.21^{* *}$ & $<0.001$ & $20.13^{* *}$ & $<0.001$ \\
TDZ concentration (T) & $710.67^{* *}$ & $<0.001$ & $141.96^{* *}$ & $<0.001$ \\
Position of explant on & $279.06^{* *}$ & $<0.001$ & $87.89^{* *}$ & $<0.001$ \\
culture medium (P) & $8.08^{* *}$ & 0.006 & $6.62^{*}$ & 0.012 \\
$\mathrm{C} \times \mathrm{T}$ & $4.95^{* *}$ & $<0.001$ & $0.48 \mathrm{~ns}$ \\
$\mathrm{C} \times \mathrm{P}$ & $30.95^{* *}$ & $<0.001$ & $5.6^{* *}$ & 0.842 \\
$\mathrm{~T} \times \mathrm{P}$ & $2.45^{* *}$ & 0.027 & $0.19 \mathrm{~ns}$ & 0.001 \\
$\mathrm{C} \times \mathrm{T} \times \mathrm{P}$ & & & 0.986 \\
\hline
\end{tabular}

ns $=$ not significant, ${ }^{*}=$ significant at the $5 \%$ level $(p<0.05),{ }^{* *}=$ significant at the $1 \%$ level $(p<0.01)$.

Regeneration ability and genotypic difference are primary factors that may impact the responses of plant tissue cultures. There were significant differences in the shoot formation frequency between the tested cultivars in the present study. "Snowy" leaf explants manifested a significantly higher mean shoot formation frequency (38.84\%) in comparison with the "Midnight Purple" cultivar (32.49\%) (Figure 4a) and exhibited a higher mean number of shoots per explant (Figure 4b). The results showed that shoot regeneration ability was greatly affected by the genotype used. Morphogenetic ability dependence from the genotype has been previously observed for many ornamental plants [7,26-29].

Culture medium composition, especially growth regulators, is another important factor affecting organogenesis in vitro. The effect of TDZ on shoot organogenesis and somatic embryogenesis has been reported in many plant species [30-32]. Mundhara and Rashid [33] observed a correlation between root repression and shoot induction by TDZ in intact seedlings of Linum usitatissimum. Further, they found that BAP also led to root inhibition and shoot formation, but only at a higher $(10 \mathrm{mM})$ concentration. TDZ applied at low concentrations stimulated shoot formation, and at high concentrations it induced somatic embryogenesis in some ornamental plants-for example, Saintpaulia ionantha [7,34] and Ochna integerrima [35].

(a)

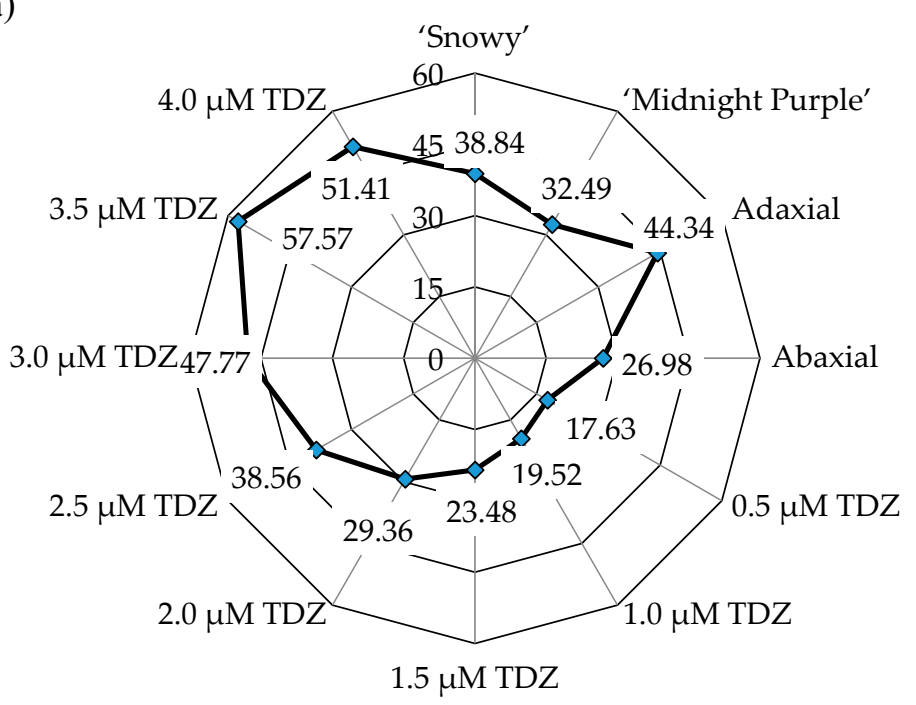

Figure 4. Cont. 
(b)

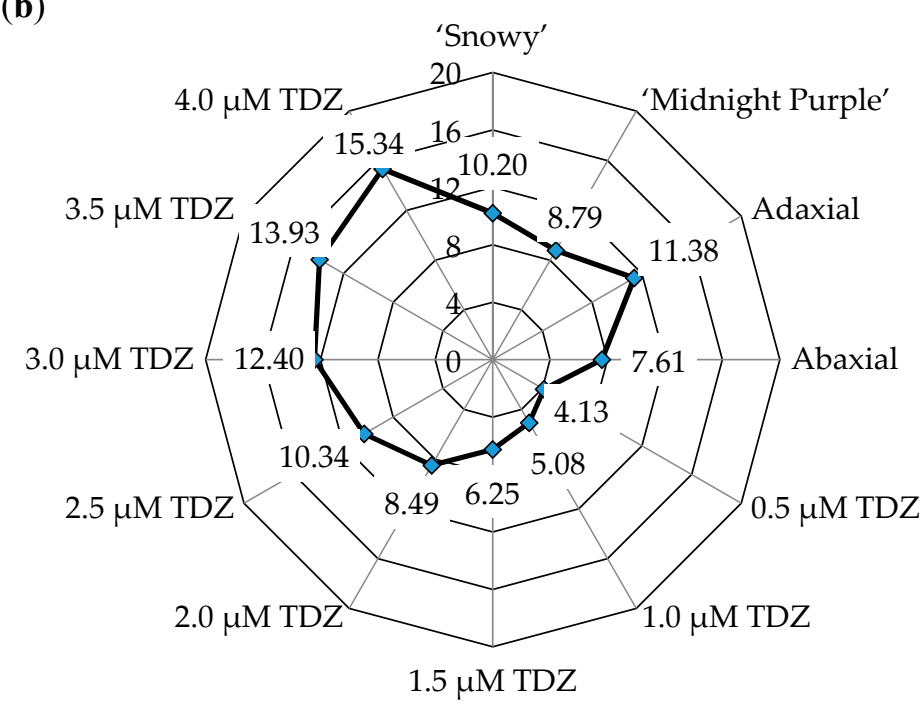

Figure 4. Effect of different factors on mean shoot formation frequency (a) and mean number of shoots per explant (b) in both cultivars.

In this investigation, the percentage of responses of explants forming shoot buds increased in all variants tested, with an increase in TDZ concentration up to a level of $3.5 \mu \mathrm{M}$ (Figure 3). Further increasing the TDZ concentration only increased the shoot formation frequency from explants of the "Midnight Purple" cultivar placed with the abaxial side on the induction medium (Figure 3b). Moreover, higher levels of TDZ stimulated no somatic embryogenesis or callus formation. Our results showed that the concentration of TDZ in the induction medium had a significant impact on the shoot formation frequency of leaf discs and the number of shoots per explant. Kumar and Reddy [36] reported that the highest shoot formation frequency and number of shoots per explant was found on MS medium supplemented with $2.27 \mu \mathrm{M}$ TDZ in a somatic tissue culture of Jatropha curcas. The best organogenic response from leaf explants of Primulina tamiana was gained on medium with $2.5 \mu \mathrm{M}$ TDZ [9]. The present investigation showed that the medium with $3.5 \mu \mathrm{M}$ TDZ promoted the highest organogenesis frequency (Figure 4a), while the largest shoot number per explant was determined on the medium with $4.0 \mu \mathrm{M}$ TDZ (Figure $4 \mathrm{~b}$ ).

The present study illustrated that the development of adventitious shoots from leaf explants of the investigated gloxinia cultivars depended not only on the combination of PGRs (plant growth regulators) and their interactions with genotype but also on the orientation of the explant on the culture medium. Leaf discs of the tested cultivars cultured on the medium with the adaxial side down revealed a significantly higher $(p<0.01)$ shoot regeneration frequency $(44.34 \%)$ in comparison with those cultured on the medium with the abaxial side down (26.98\%) (Figure 4a), which exhibited a higher mean number of shoots per explant (Figure $4 \mathrm{~b}$ ). Similar results were obtained in our earlier study with petunia [29]. In contrast, the leaf discs of Primulina tamiana placed with the abaxial side on the medium generated more shoots compared to those with the adaxial side [9].

\subsection{Root Formation and Plantlets Acclimatization}

For root induction, elongated shoots were cultured on the MS medium with $0.1 \mathrm{mg} \mathrm{L}^{-1} \mathrm{NAA}$. Root formation was induced within two weeks, and all shoots contained roots after four weeks (Figure $5 \mathrm{a}$ ). When plantlets with roots were moved to the greenhouse, more than $98 \%$ of them survived and were growing normally (Figure $5 b$ ). The regenerants developed flowers and were identical to the donor plants. 

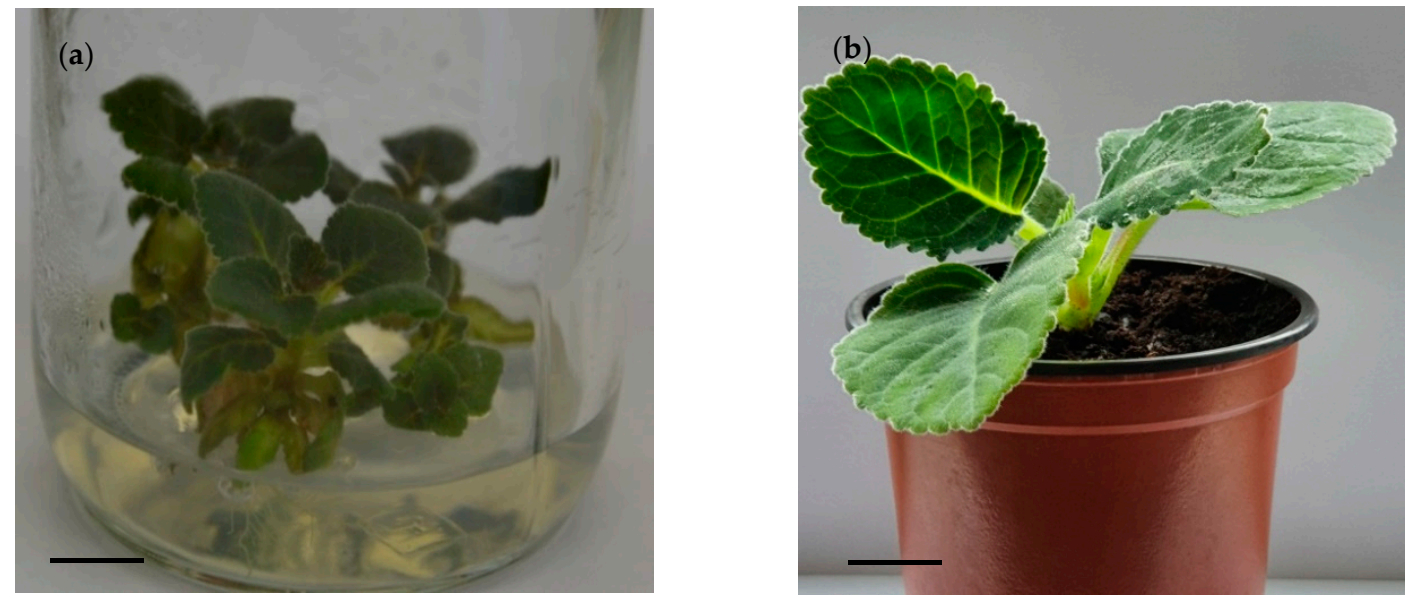

Figure 5. Rooted shoots on the rooting medium (a) and a hardened regenerated plant (b).

\section{Conclusions}

The significant differences in shoot formation frequency between the cultivars were obtained. "Snowy" leaf explants of manifested a significantly higher mean shoot formation frequency as well as a higher mean number of shoots per explants in comparison with the "Midnight Purple" cultivar. The explants of the tested cultivars cultured on the medium with the adaxial side down showed a significantly higher shoot formation frequency in comparison with explants cultured on the medium with the abaxial side down, and they showed a higher mean number of shoots per explant. Both tested cultivars produced the highest number of regenerated shoots by cultured leaf discs on the medium supplemented with $3.5 \mu \mathrm{M}$ TDZ with the adaxial side down. The efficient in vitro organogenesis system reported in this study which involves a single step of organogenesis could potentially be useful for the micropropagation or transformation of Sinningia speciosa, an economically important ornamental plant.

Author Contributions: Conceptualization, A.B. and N.B.; methodology, A.B. and N.B.; software, V.J.; validation, A.B. and N.B.; formal analysis, A.B. and N.B.; investigation, V.J. and R.M.; resources, N.B.; data curation, V.J.; writing—original draft preparation, A.B. and N.B.; writing-review and editing, A.B., N.B., V.J. and R.M.; visualization, A.B. and N.B.; supervision, A.B. All authors have read and agreed to the published version of the manuscript.

Funding: This research received no external funding.

Conflicts of Interest: The authors declare no conflict of interest.

\section{References}

1. Scaramuzzi, F.; Apollonio, G.; D’Emerico, S. Adventitious shoot regeneration from Sinningia speciosa leaf discs in vitro and stability of ploidy level in subcultures. Vitr. Cell Dev. Biol.-Plant 1999, 35, 217-221. [CrossRef]

2. Nhut, D.T.; Phu, T.H.; Huyen, P.X.; Thuy, D.T.T. Effects of in vitro leaf explants and leaf size on direct shoot regeneration of gloxinia. Propag. Ornam. Plants 2007, 7, 16-22.

3. Takagi, H.; Sugawara, S.; Saito, T.; Tasaki, H.; Yuanxue, L.; Kaiyun, G.; Han, D.S.; Godo, T.; Nakano, M. Plant regeneration via direct and indirect adventitious shoot formation and chromosome-doubled somaclonal variation in Titanotrichum oldhamii (Hemsl.) Solereder. Plant Biotechnol. Rep. 2011, 5, 187-195. [CrossRef]

4. Chautems, A.; Baracho, G.S.; Filho, J.S. A new species of Sinningia (Gesneriaceae) from northeastern Brazil. Brittonia 2000, 52, 49-53. [CrossRef]

5. Zaitlin, D.; Pierce, A.J. Nuclear DNA content in Sinningia (Gesneriaceae); intraspecific genome size variation and genome characterization in S. speciosa. Genome 2010, 53, 1066-1082. [CrossRef]

6. Rout, G.R.; Mohapatra, A.; Jain, S.M. Tissue culture of ornamental pot plant. A critical review on present scenario and future prospects. Biotechnol. Adv. 2006, 24, 531-560. [CrossRef] [PubMed] 
7. Mithila, J.; Hall, J.C.; Victor, J.M.R.; Saxena, P.K. Thidiazuron induces shoot organogenesis at low concentrations and somatic embryogenesis at high concentrations on leaf and petiole explants of African violet (Saintpaulia ionantha Wendl.). Plant Cell Rep. 2003, 21, 408-414. [CrossRef]

8. Cui, J.; Chen, J.J.; Henny, R.J. Regeneration of Aeschynanthus radicans via direct somatic embryogenesis and analysis of regenerants with flow cytometry. Vitr. Cell Dev. Biol. Plant 2009, 45, 34-43. [CrossRef]

9. Padmanabhan, P.; Murch, S.J.; Sullivan, J.A.; Saxena, P.K. Development of an efficient protocol for high frequency in vitro regeneration of a horticultural plant Primulina tamiana (B.L. Burtt) Mich. Möller \& A. Webber. Can. J. Plant Sci. 2014, 94, 1281-1287.

10. Pang, J.L.; Wang, L.L.; Hu, J.Q.; Xiang, T.H.; Liang, H.M. Synergistic promotion of gibberellin and cytokinin on direct regeneration of floral buds from in vitro cultures of sepal segments in Sinningia speciosa Hiern. Vitr. Cell Dev. Biol. Plant 2006, 42, 450-454. [CrossRef]

11. Pang, J.; Wang, L.; Xiang, T.; Zhong, D.; Yu, H. High-frequency floral bud regeneration from petal segment cultures of Sinningia speciosa Hiern. Chin. J. Cell Biol. 2012, 34, 279-285.

12. Macas-Palacios, G.C.; Pucha-Pauta, E.E.; Delgado-Paredes, G.E.; Rojas-Idrogo, C.; Minchala-Patino, J. In vitro plant regeneration in gloxinia (Sinningia speciosa (Lodd.) Hiern.). J. Biol. 2015, 3, 6-14.

13. Xu, Q.L.; Hu, Z.; Li, C.Y.; Wang, X.Y.; Wang, C.Y. Tissue culture of Sinningia speciosa and analysis of the in vitro-generated tricussate whorled phyllotaxis (twp) variant. Vitr. Cell Dev. Biol. Plant 2009, 45, 583-590. [CrossRef]

14. Park, E.H.; Bae, H.; Park, W.T.; Kim, Y.B.; Chae, S.C.; Park, S.U. Improved shoot organogenesis of gloxinia (Sinningia speciosa) using silver nitrate and putrescine treatment. Plant Omics 2012, 5, 6-9.

15. Sharma, S.K.; Sharma, M. Improved protocol for in vitro propagation of gloxinia (Sinningia sp.). J. Cell Tissue Res. 2013, 13, 3545-3548.

16. Zhou, G.Y.; Zhou, W.H.; Cheng, L. Preliminary study on dormancy of gloxinia in vitro. Acta Agric. Shanghai 2000, 16, 69-72.

17. Lu, C. The use of thidiazuron in tissue culture. Vitr. Cell Dev. Biol. Plant 1993, 29, 92-96. [CrossRef]

18. Singh, N.D.; Sahoo, L.; Sarin, N.B.; Jaiwal, P.K. The effect of TDZ on organogenesis and somatic embryogenesis in pigeonpea (Cajanus cajan (L.) Millsp). Plant Sc. 2003, 164, 341-347. [CrossRef]

19. Lata, H.; Chandra, S.; Wang, Y.H.; Raman, V.; Khan, I.A. TDZ-induced high frequency plant regeneration through direct shoot organogenesis in Stevia rebaudiana Bertoni: An important medicinal plant and a natural sweetener. Am. J. Plant Sci. 2013, 4, 117-128. [CrossRef]

20. Vujovic, T.; Ruzic, D.; Cerovic, R.; Momirovic, G.S. Adventitious regeneration in blackberry (Rubus fruticosus L.) and assessment of genetic stability in regenerants. Plant Growth Regul. 2010, 61, 265-275. [CrossRef]

21. Cappelletti, R.; Sabbadini, S.; Mezzetti, B. The use of TDZ for the efficient in vitro regeneration and organogenesis of strawberry and blueberry cultivars. Sci. Hortic. 2016, 207, 117-124. [CrossRef]

22. Guo, B.; Abbasi, B.H.; Zeb, A.; Xu, L.L.; Wei, Y.H. Thidiazuron: A multi-dimensional plant growth regulator. Afr. J. Biotechnol. 2011, 10, 8984-9000.

23. Murashige, T.; Skoog, F. A revised medium for rapid growth and bioassays with tobacco tissue cultures. Physiol. Plantarum 1962, 15, 473-497. [CrossRef]

24. Raudonius, S. Application of statistics in plant and crop research: Important issues. Zemdirb. Agric. 2017, 104, 377-382. [CrossRef]

25. Compton, M.E. Statistical methods suitable for the analysis of plant tissue culture data. Plant Cell Tissue Organ Cult. 1994, 37, 217-242.

26. Datta, S.K.; Chakrabarty, D.; Saxena, M.; Mandal, A.K.A.; Biswas, A.K. Direct shoot generation from florets of chrysanthemum cultivars. J. Genet. Plant Breed. 2001, 61, 373-376.

27. Chen, X.; Kane, M.E.; Chen, J. Effect of genotype, explant source, and plant growth regulators on indirect shoot organogenesis in Dieffenbachia cultivars. Vitr. Cell Dev. Biol. Plant 2008, 44, 282-288.

28. Yusnita, Y.; Pungkastiani, W.; Hapsoro, D. In vitro organogenesis of two Sansevieria cultivars on different concentrations of benzyladenine (BA). Agrivita 2011, 33, 147-153.

29. Burbulis, N.; Blinstrubienè, A.; Jonytienè, V. In vitro regeneration from leaf explants of Petunia hybrida L. Propag. Ornam. Plants 2015, 15, 47-52.

30. Murthy, B.N.S.; Murch, S.J.; Saxena, P.K. Thidiazuron: A potent regulator of in vitro plant morphogenesis. Vitr. Cell Dev. Biol. Plant 1998, 34, 267-275. [CrossRef] 
31. Murch, S.J.; Saxena, P.K. Molecular fate of thidiazuron and its effects on auxin transport in hypocotyl tissues of Pelargonium hortorum Bailey. Plant Growth Regul. 2001, 35, 269-275. [CrossRef]

32. Jones, M.P.A.; Cao, J.; O’Brien, R.; Murch, S.J.; Saxena, P.K. The mode of action of thidiazuron: Auxins, indoleamines, and ion channels in the regeneration of Echinacea purpurea L. Plant Cell Rep. 2007, 26, 1481-1490. [CrossRef] [PubMed]

33. Mundhara, R.; Rashid, A. TDZ-induced triple-response and shoot formation on intact seedlings of Linum, putative role of ethylene in regeneration. Plant Sci. 2006, 170, 185-190. [CrossRef]

34. Taha, R.M.; Daud, N.; Hasbullah, N.A.; Awal, A. Somatic embryogenesis and production of artificial seeds in Saintapaulia ionantha Wendl. Acta Hortic. 2009, 829, 331-336. [CrossRef]

35. Ma, G.H.; Lu, J.; da Silva, J.A.T.; Zhang, X.; Zhao, J. Shoot organogenesis and somatic embryogenesis from leaf and shoot explants of Ochna integerrima (Lour.). Plant Cell Tissue Organ Cult. 2011, 104, 157-162. [CrossRef]

36. Kumar, N.; Reddy, M.P. Thidiazuron (TDZ) induced plant regeneration from cotyledonary petiole explants of elite genotypes of Jatropha curcas: A candidate biodiesel plant. Ind. Crop. Prod. 2012, 39, 62-68. [CrossRef]

Publisher's Note: MDPI stays neutral with regard to jurisdictional claims in published maps and institutional affiliations.

(C) 2020 by the authors. Licensee MDPI, Basel, Switzerland. This article is an open access article distributed under the terms and conditions of the Creative Commons Attribution (CC BY) license (http://creativecommons.org/licenses/by/4.0/). 